\title{
Comparative Kinetic Study of Anaerobic Treatment of Thermally Pretreated Source-Sorted Organic Market Refuse
}

\author{
Aritra Das and Chanchal Mondal \\ Department of Chemical Engineering, Jadavpur University, Kolkata, West Bengal 700032, India \\ Correspondence should be addressed to Aritra Das; aritra@research.jdvu.ac.in
}

Received 15 September 2015; Accepted 3 December 2015

Academic Editor: Francesco Frusteri

Copyright ( 2015 A. Das and C. Mondal. This is an open access article distributed under the Creative Commons Attribution License, which permits unrestricted use, distribution, and reproduction in any medium, provided the original work is properly cited.

\begin{abstract}
The present study deals with extensive investigations of the effect of thermal pretreatment on whole-sale market rejects for their biogas production potential. Market reject considered as biomass for this study has been treated at two different temperatures $85^{\circ} \mathrm{C}$ and $135^{\circ} \mathrm{C}$ for $8 \mathrm{~h}$ each and subjected as feedstock for anaerobic digestion $(\mathrm{AD})$ process. The $\mathrm{AD}$ process has been operated in the mesophilic range $\left(35-38^{\circ} \mathrm{C}\right)$ of bacterial growth. Various kinetic models have been used to simulate the experimental data. Kinetic modeling revealed that biogas production rate exhibited better coefficient of determination $\left(R^{2}\right)$ in the range of $0.973-0.989$ with exponential model for the ascending limb whereas the descending limb resulted in good linear correlation with $R^{2}$ as $0.911-0.976$. Logistic growth model and Gompertz relation simulation of cumulative biogas production resulted in better $R^{2}$ values in the range of $0.994-0.997$ and $0.998-0.999$, whereas the $R^{2}$ values for exponential rise to maximum plots ranged from 0.722 to 0.800 .
\end{abstract}

\section{Introduction}

Anaerobic digestion (AD) is the process of waste treatment leading to biogas sanitation. Several biodegradable substances freely occurring in the environment in the form of market refuse, organic kitchen wastes, farm wastes, yard wastes, sewage, manures, and so forth together form municipal solid waste possessing enough potential for energy recovery to be utilized as substitute for nonrenewable sources of energy. $\mathrm{AD}$ is well-suited waste treatment technique for wastes containing higher levels of organic matter and much less expensive than aerobic waste treatment processes as there is no requirement of energy for aeration systems and nevertheless the volatile solid removal rate from the wastes is higher due to rapid volatilization of wastes to biogas. Biogas can be upgraded to the quality of natural gas and can be further used for power automobiles. Methane $\left(\mathrm{CH}_{4}\right)$ is a potential component of biogas that possesses a calorific value of $6 \mathrm{kwh} / \mathrm{m}^{3}$ that corresponds to half a litre of diesel oil [1]. The resulting sludge from the process is biologically more or less stable and rich in nutrients which makes it a valuable soil conditioner and fertilizer. Regular withdrawing of biogas produces the chances of global warming and gives a source of renewable energy. The composition of biogas is mostly methane (50-75\%), carbon dioxide (25-50\%), hydrogen (5$10 \%)$, nitrogen (1-2\%), and hydrogen sulphide (traces) [1-3].

The process is globally carried out in four steps, namely, hydrolysis, fermentation and acidification, acetogenesis, and methanogenesis (Figure 2). These sequential stages are carried out by separate microbial populations, namely, the hydrolytic, fermenting, acetogenic, and methanogenic bacteria. None of the groups can produce biogas alone and hence they work together unitedly to synthesize biogas [1]. The cleavage of a chemical compound through reaction with water is known as hydrolysis. A hydrogen atom gets attached to one side of the split chain of compound and the remaining hydroxyl group of water gets attached to the other side. Hydrolysis is the first step of $\mathrm{AD}$ process where carbohydrates are broken down to sugars, proteins to amino acids, fats to fatty acids, and so on. The second step of AD process is fermentation where the fermentative bacteria transform sugars and other organic products of the hydrolysis step to organic acids, alcohols, hydrogen, carbon dioxide, and ammonia. Acetogenesis is the third step of $\mathrm{AD}$ process where the acetogenic bacteria utilize the products of the fermentation step and produce hydrogen, carbon dioxide, and acetic acid 
by utilizing present carbon of biomass and the dissolved or bound oxygen. Hence, the acid producing bacteria create anaerobic environment for the methanogens. Further, methanogenesis is the final step of AD process where the carbon dioxide, hydrogen, and acetic acid are converted to methane and carbon dioxide and variable trace quantities of nitrogen, hydrogen sulphide, and other components. Operating temperature is one of the important process parameters needed for the design of biogas generation [4]. Likewise, other essential process parameters to be considered are $\mathrm{pH}$, $\mathrm{TS}, \mathrm{C} / \mathrm{N}$ ratio, $\mathrm{COD}$, mixing, and reactor setup.

Though anaerobic treatment is one of the best methods for efficient solid waste management, the kinetics of the process is very slow. Thermal pretreatment of the wastes carried out in this research work has been observed to improve the kinetics of AD process in terms of higher biogas yield as compared to the process with untreated wastes within the same hydraulic retention time of 45 days under mesophilic conditions $\left(35-38^{\circ} \mathrm{C}\right)$. The increased interest in the process stimulated the idea of mathematical modelling and simulation which is much less expensive than performing extensive laboratory experiments. Application of sophisticated methods of process control is only possible if mathematical models are available for the system to be optimized. Several simulation models of AD process have been proposed [5-13]. The models described require simultaneous solutions of mass balance equations for each individual substrate and bacterial population, yielding equations with numerous unknown parameters. Hence, a simpler approach has been made in this study to describe the anaerobic biogas fermentation process.

This work primarily deals with study of the biogas production kinetics for the description and evaluation of methanogenesis by fitting the experimental data of biogas production to linear, exponential, and Gaussian equations. In addition the cumulative biogas production has been simulated using logistic growth model, exponential rise to maximum, and modified Gompertz plots.

The main goal of our work is to compare and contrast between low and high temperature treated and untreated wastes. The extensive research work during this course of study has been carried out from January 2015 to March 2015 in the Energy and Combustion Laboratory, Department of Chemical Engineering, Jadavpur University, Kolkata, India.

\section{Materials and Methods}

2.1. Sample Collection and Preparation. Source-sorted OFMSW has been collected locally from places in and around Jadavpur University campus, cleaned, and sun dried for 2 days with exposure to bright sunlight for 8 hours daily in accordance with the working hours of the University in order to remove the superficial moisture. After sufficient drying, bone dry biomass has been graded and sorted to prevent inclusion of unwanted and possible contaminant materials (detergents, sand, dirt, dust, bones, etc.).

Further the dried materials have been charged for particle size reduction using a Wiley mill (make: DLF Motors India Pvt. Ltd.) and passed through IS sieves of size $7 \mathrm{~mm}$. The

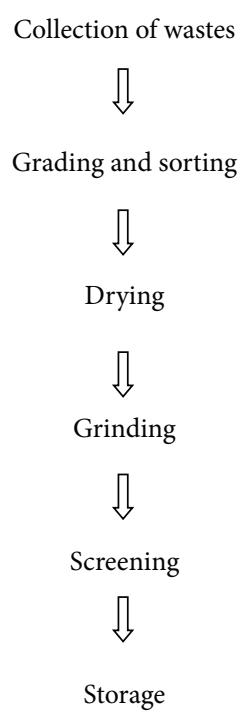

FIGURE 1: Flowsheet for feedstock and inoculum preparation.

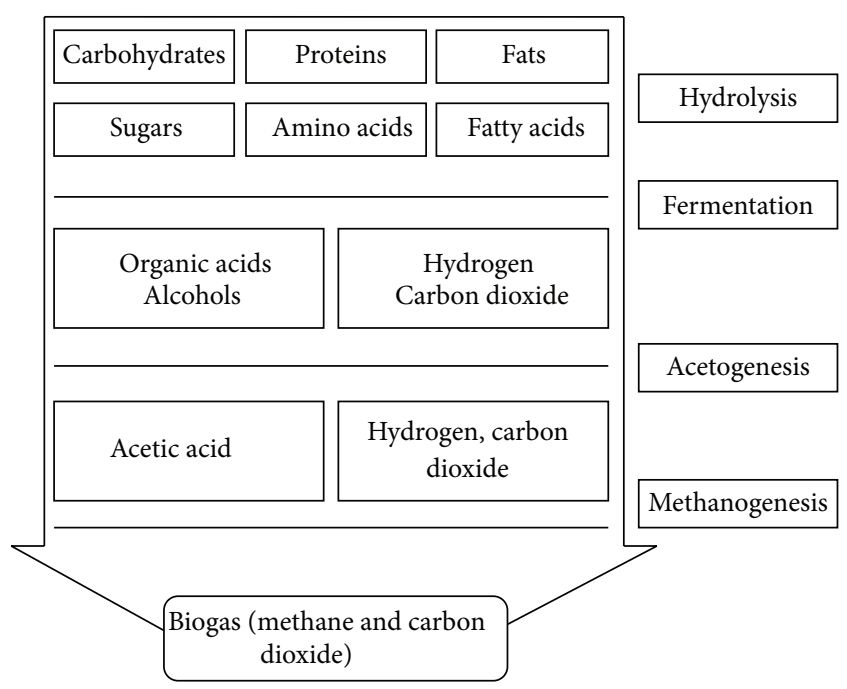

FIGURE 2: Schematic diagram showing the sequential steps of biogas generation.

free-flowing finely ground and screened sample of OFMSW has been stored in air tight vessel to prevent absorption of atmospheric moisture, till use as feed material for AD.

Fresh cattle manure (CM) has been obtained from nearby cow shed around the University campus where cows are fed with special feed consisting of silage, hay forage, agricultural residues, flour mill residues, and so forth. Finally, CM has been collected from randomly selected 5 cows and sun dried on plastic trays for 2 days. Similarly, the dried CM has been finely ground using ball mill (make: SC Dey \& Co.) and strained using IS sieves of $1 \mathrm{~mm}$ size, filled in containers (Scott-Duran), and kept in refrigerator at $4^{\circ} \mathrm{C}$ till further use.

2.2. Inoculum Preparation (Figure 1). Fresh CM slurry has been used as inoculum in this study, as it contains all the required groups of microbial consortium essential for $\mathrm{AD}$ 
process. S/I ratio has been maintained as 2 for this study and accordingly requisite amount of CM has been soaked in distilled water and stirred at $500 \mathrm{rpm}$ using a magnetic stirrer for $30 \mathrm{~min}$ to form slurry and kept in incubator at $37^{\circ} \mathrm{C}$ for 7 days. Later the conical flask and its contents have been kept in refrigerator at $4^{\circ} \mathrm{C}$ until use. Prior to use the inoculum has been incubated for one week at $37^{\circ} \mathrm{C}$ with constant mixing to reactivate microbiological activity. The $\mathrm{pH}$, total solid, and volatile solid of the inoculum have been determined, discussed in characterization subsection, and tabulated in Table 2.

2.3. Thermal Pretreatment. Thermal treatment has been widely studied earlier and most successfully applied at industrial scale operations [14-16] but no systematic research works on various temperatures and treatment times have been done to enhance the biodegradability of OFMSW. Thermal treatment causes disintegration of cell membrane leading to solubilization of organic compounds [17-20]. Heating has been achieved by various methods, namely, steam, electric, and microwave. No significant difference has been observed between steam and electric heating though microwave heating solubilized more biopolymers [21]. In present study, thermal pretreatment at both low $\left(<110^{\circ} \mathrm{C}\right)$ and high $\left(>110^{\circ} \mathrm{C}\right)$ temperature has been studied. Heating of biomass has been achieved by means of electric heating in a hot air oven (make: SICCO Instruments). For instance preheating at $85^{\circ} \mathrm{C}$ and $135^{\circ} \mathrm{C}$ has been conducted for $8 \mathrm{~h}$, respectively, and resulted in enhancement of biogas production as compared to that of untreated biomass. A trial experiment has also been conducted at preheating conditions of $165^{\circ} \mathrm{C}$ and did not result in any enhancement of biogas production; rather hardening and darkening of biomass have been observed and hence are not reported in present study. The dark brownish color development of the substrate indicated occurrence of Maillard reactions. In this regard, for lignocellulosic biomass, temperatures above $160^{\circ} \mathrm{C}$ results in solubilization of hemicellulose and lignin, which are phenolic compounds inhibitory to anaerobic microbial consortium [22]. Exposure of substrate to severe conditions can result in loss of volatile organic matter and decrease the potential biogas production [23]. Hence, higher solubilization of substrate components can be achieved with lower temperature but longer retention times [23].

2.4. Feedstock Preparation. Thermally pretreated and untreated samples of OFMSW have been mixed with inoculum prior to use as feed to bioreactor. Table 2 represents the results of characterization of biomass on dry weight basis. A study reported that total solid content in the range of 7.4-9.2\% with CM exhibits best performance for digestibility [24]. Similarly another study [4] reported that for $\mathrm{CM}$ at $35^{\circ} \mathrm{C}$ temperature maximum gas production has been obtained with $8 \%$ total solid. In present study, a higher TS content of $15 \%$ and initial substrate concentration of $100 \mathrm{~g} \mathrm{~L}^{-1}$ have been maintained for all the reactors. Hence, biomass and inoculum have been mixed with soft water in such a manner that the total solid content of test reactor is maintained at $15 \%$ of the effective volume of reactor. S/I ratio

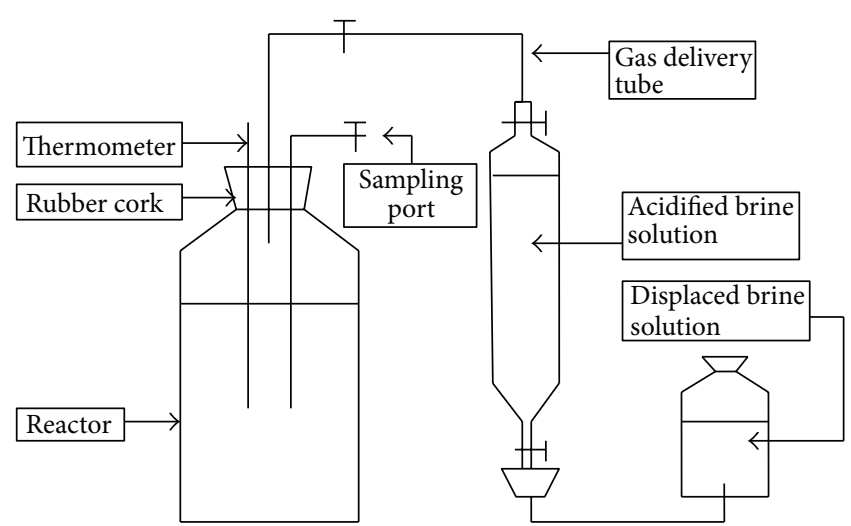

FIGURE 3: Schematic diagram of experimental setup.

has been maintained as 2 on the basis of total solid content of the test reactor. The characterization results revealed that biomass possesses sufficient volatile matter indicating good potential for generation of biogas.

\subsection{Experimental Procedure}

2.5.1. Setup of Test Reactors. The schematic diagram of the experimental setup is shown in Figure 3. It consists of a completely randomized arrangement of bench top batch reactors in a $3 \times 3$ replicated laboratory experiment and has been conducted in a series of 3 laboratory aspirator bottles made of borosilicate glass of $1000 \mathrm{~mL}$ capacity each. Rubber cork has been fitted tightly to the neck of each bottle to help maintain the anaerobic environment. Three glass tubes made of borosilicate glass have been fitted to rubber cork tightly. Each glass tube consisted of a glass knob or valve at the opening end. Among three tubes one of them has been used as gas delivery tube and the other two have been kept dipped in slurry, one for sampling out from time to time for determination of $\mathrm{pH}$, total solid, and volatile solid. A cylindrical jar essentially fitted with glass knobs or valves at both ends, made of borosilicate glass and with $500 \mathrm{~mL}$ capacity, has been used for measuring biogas by water displacement method. The gas delivery tube has been connected to one end of the jar by means of rubber tube. Similarly the other end of the tube has been connected to a glass jar of $500 \mathrm{~mL}$ capacity to facilitate the volume of displaced water upon commencement of biogas into the jar.

A weighing balance has been utilized for measuring the required mass of cattle manure and biomass. The constant temperature of the processes has been maintained by putting the bench top reactors into an incubator (make: SC Dey \& Co.). A digital pH meter (make: Eutech Instruments, Singapore) has been used to determine $\mathrm{pH}$ of the fermentation slurry at an interval of 48 hours. Certain drop in $\mathrm{pH}$ of fermentation slurry has been adjusted by the addition of 4 to 5 drops of $6 \mathrm{~N} \mathrm{NaOH}$ solution. The entire experiment has been conducted for a period of 45 days till significant reduction in the production of biogas. Apart from test reactors, CM has been digested alone at a loading rate of $100 \mathrm{~g} \mathrm{~L}^{-1}$ as a control reactor against all the test reactors so 
TABLE 1

\begin{tabular}{|c|c|c|c|c|c|c|c|}
\hline \multirow{2}{*}{ Reactors } & \multicolumn{4}{|c|}{ Ultimate biogas yield } & \multicolumn{3}{|c|}{ Energy equivalent } \\
\hline & $\mathrm{mL} / \mathrm{g} \mathrm{VS}$ & Millilitres (mL) & Litres (L) & Cubic meter $\left(\mathrm{m}^{3}\right)$ & Calories (cal) & Kilo calories (kcal) & Total (kcal) \\
\hline Group A (pretreated sample) & 137.73 & 11362.73 & 11.36 & $11.36 \times 10^{-3}$ & 59730.88 & 59.73 & \multirow{4}{*}{148.11} \\
\hline Group B (pretreated sample) & 101.76 & 8395.20 & 8.39 & $8.39 \times 10^{-3}$ & 44114.62 & 44.11 & \\
\hline Group C & 89.35 & 7371.37 & 7.37 & $7.37 \times 10^{-3}$ & 38751.46 & 38.75 & \\
\hline Group D & 44.81 & 1053.04 & 1.05 & $1.05 \times 10^{-3}$ & 5520.9 & 5.52 & \\
\hline
\end{tabular}

TABLE 2: Properties of feedstock and inoculum.

\begin{tabular}{lcccccccc}
\hline \multirow{2}{*}{ Source } & \multicolumn{9}{c}{ Characteristics of OFMSW and CM cake (dry weight basis) } \\
& MC (\%) & TS (\%) & VS (\%) & VS/TS (\%) & Ash (\%) & FC (\%) & BD (g/L) & pH \\
\hline OFMSW & $5.16 \pm 0.11$ & $94.93 \pm 0.11$ & $78.66 \pm 0.57$ & $70.51 \pm 2.40$ & $5.66 \pm 0.57$ & $15.66 \pm 0.57$ & $315 \pm 2.64$ & ND \\
CM cake & $11.13 \pm 0.11$ & $88.8 \pm 0.11$ & $62.66 \pm 2.08$ & $82.86 \pm 0.66$ & $22.33 \pm 0.57$ & $15.00 \pm 1.73$ & $282 \pm 2.08$ & $6.5 \pm 0.07$ \\
\hline
\end{tabular}

Data shown are the average and standard deviation based on triplicate runs (mean value \pm SD); $\mathrm{ND}=$ not determined.

as to monitor the performance of $\mathrm{AD}$ process of untreated and treated biomass. All the reactors have been subjected to gentle shaking and swirling prior to monitoring of gas production, once in every 24 hours to maintain intimate contact of microorganisms with the substrate. The reactors with individual processes have been designated as group A (biomass treated at $135^{\circ} \mathrm{C}$ ), group B (biomass treated at $85^{\circ} \mathrm{C}$ ), group $\mathrm{C}$ (untreated biomass), and group $\mathrm{D}$ (control reactor consisting of inoculum). Biogas production has been observed to be slow at the beginning and end of AD process because in batch reactors biogas production directly corresponds to the specific growth rate of methanogens [24, 25]. During this process a small amount of atmospheric air enters the headspace but in insufficient quantities to affect the redox conditions in the reactor: any nitrogen detected in the gas composition is corrected for, as this is not normally produced as a result of the digestion process [26].

2.5.2. Setup of Biogas Measurement. In order to prevent the dissolution of biogas into water, brine solution has been prepared and used to measure yield of biogas by displacement of water (Table 1). Acidified brine solution has been prepared according to the process mentioned by [27]. Laboratory grade sodium chloride has been dissolved in distilled water until formation of a supersaturated solution and further amount of 4 to 5 drops of concentrated sulfuric acid has been added to lower the $\mathrm{pH}$. As soon as the glass cork of delivery tube was opened, the positive pressure of biogas within the reactor caused the biogas to flow through the delivery tube and a pressure gradient provided the driving force for displacement of the solution to adjacent bottle connected to the gas measuring jar by means of rubber pipe. Hence, the displaced volume of brine solution has been measured and considered as the amount of biogas produced. Biogas yield has been monitored daily and measured after every 72-hour interval. All gas volumes have been reported as correct to STP of $0^{\circ} \mathrm{C}$ and $101.325 \mathrm{kPa}$.
TABLE 3: Ultimate properties of OFMSW and CM cake.

\begin{tabular}{lcc}
\hline Source & $\begin{array}{c}\text { Ultimate properties of OFMSW and CM cake } \\
\text { (dry weight basis) }\end{array}$ \\
\hline & $\mathrm{C}: \mathrm{N}$ & Calorific value \\
& & $(\mathrm{J} / \mathrm{g})$ \\
OFMSW & 3892 \\
CM cake & 22.45 & 3280 \\
\hline
\end{tabular}

2.6. Analytical Methods. Moisture content, total solids (TS), volatile solids (VS), ash content, and fixed carbon, indicated in Table 2 has been determined according to the standard method stated by Fuel Research Board and British Standard Institution [28]. Bulk density has been determined using suitable method involving a graduated measuring cylinder estimating the weight of a known volume. $\mathrm{pH}$ has been determined using bench meter (Eutech Instruments, Singapore) with a combination of glass electrode calibrated in buffers 4, 7 and 10. Calorific value of biomass has been determined using Karas-Simek bomb calorimeter following the method of [28]. The temperature-time plot for calorific value determination has been represented in Figure 4. Elemental composition $(\mathrm{C}, \mathrm{H}$, and $\mathrm{N}$ ) has been analyzed using Elemental Analyzer of Indian Association for the Cultivation of Science and presented in Table 3. The values of VS destructions have been calculated for each reactor before and after the digestion test by subtracting the VS contents of the control reactor from that of the test reactor.

\section{Simulation of Biogas Production}

Kinetic study of biogas production has been conducted for description and evaluation of methanogenesis by fitting the experimental data of biogas production to various kinetic equations. Biogas production rates of biomass digested with CM have been simulated using linear, exponential, Gaussian, 


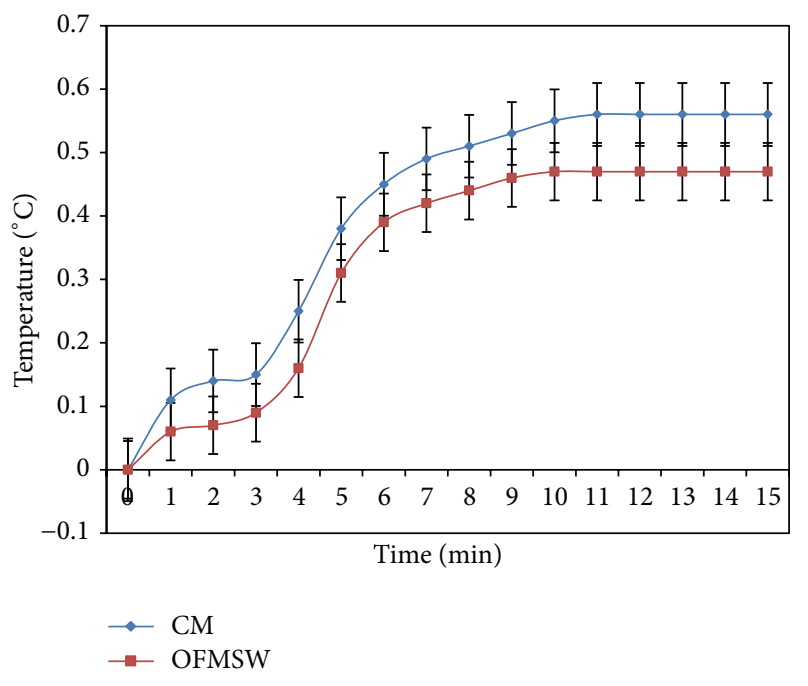

Figure 4: Temperature-time plot for determination of calorific value.

and Gompertz plots. It has been assumed that biogas production rate increases linearly with increase in time and after reaching a peak value it decreases linearly to a low significant value. The linear equation for biogas production rate can be expressed by the equation below $[4,11,12]$ :

$$
y=a+b T
$$

where $y$ is biogas production rate $\left(\mathrm{mLg}^{-1} \mathrm{VS} \mathrm{d}^{-1}\right), T$ is hydraulic retention time in days, and $a$ and $b$ are constants obtained from the intercept and slope of the graph plotted $y$ versus $T$. Slope $b$ is positive for the ascending limb and negative for the descending limb.

The exponential plot can be represented by (2), where it has been assumed that the biogas production rate increases exponentially with increase in time and reaches a peak value and thereafter decreases to a low significant value exponentially with increase in time. Consider

$$
y=a+b^{c T}
$$

where $y$ is biogas production rate $\left(\mathrm{mL} \mathrm{g}^{-1} \mathrm{VS} \mathrm{d}^{-1}\right), T$ is hydraulic retention time in days, $a\left(\mathrm{~mL} \mathrm{~g}^{-1} \mathrm{VS} \mathrm{d}^{-1}\right), b$ $\left(\mathrm{mL} \mathrm{g}^{-1} \mathrm{~d}^{-1}\right)$, and $c\left(\right.$ day $\left.^{-1}\right)$ are constants, and $c$ is positive for the ascending limb and negative for descending limb.

The Gaussian plot including both ascending and descending limbs can be represented by (3), where it has been assumed that the biogas production rate follows normal distribution over the hydraulic retention time. Consider

$$
y=a e^{-0.5\left[\left(T-T_{0}\right) / b\right]^{2}}
$$

where $y$ is biogas production rate $\left(\mathrm{mL} \mathrm{g}^{-1} \mathrm{VS} \mathrm{d}^{-1}\right), T$ is hydraulic retention time in days, $T_{0}$ is time at which the maximum biogas production occurred, and $a\left(\mathrm{~mL} \mathrm{~g}^{-1} \mathrm{VS} \mathrm{d}^{-1}\right)$ and $b$ (day) are constants.

Logistic growth equation, Gompertz equation, and exponential rise to maximum have been used to simulate the cumulative biogas production in each case. Equations (4), (5), and (6) represent linear, Gompertz, and exponential rise to maximum models, respectively. Consider

$$
y=\frac{a}{1+b e^{-k T}}
$$

where $y$ is cumulative biogas production $\left(\mathrm{mL} \mathrm{g}^{-1} \mathrm{VS}\right), k$ is kinetic constant $\left(\right.$ day $\left.^{-1}\right), T$ is hydraulic retention time (days), and $a$ and $b$ are constants. Consider

$$
y=a e^{-b e^{-c T}}
$$

where $y$ is cumulative biogas production ( $\left.\mathrm{mL} \mathrm{g}^{-1} \mathrm{VS}\right), T$ is hydraulic retention time (days), and $a$ and $b$ are positive numbers. $a$ is biogas production potential $\left(\mathrm{mL} \mathrm{g}^{-1}\right), b$ is minimum time required to produce biogas (day), and $c$ sets the growth rate ( $y$-scaling), which are constants. Consider

$$
y=a(1-e(-k T)),
$$

where $y$ is cumulative biogas production ( $\left.\mathrm{mL} \mathrm{g}^{-1} \mathrm{VS}\right), a$ is biogas production potential $\left(\mathrm{mL} \mathrm{g}^{-1}\right), k$ is kinetic rate constant $\left(\right.$ day $\left.^{-1}\right)$, and $T$ is hydraulic retention time (days).

\section{Results and Discussions}

The research work has been carried out in order to study the influence of thermal pretreatment on the kinetics of biogas synthesis. Exhaustive investigations with thermal treatment of wastes have been carried out at both low $\left(85^{\circ} \mathrm{C}\right)$ and high $\left(135^{\circ} \mathrm{C}\right)$ temperatures for $8 \mathrm{~h}$, respectively. Thereafter the pretreated materials have been charged for AD. Biogas production rate and cumulative biogas production have been plotted against hydraulic retention time as shown in Figures 5(a) and 5(b).

Peak biogas production occurred on days $15,21,12$, and 12 for groups A, B, C, and D. Maximum biogas production rate has been observed in the order of group $\mathrm{A}(12.77 \mathrm{~mL}$ $\left.\mathrm{g}^{-1} \mathrm{VS} \mathrm{d}^{-1}\right)>$ group $\mathrm{C}\left(11.87 \mathrm{~mL} \mathrm{~g}^{-1} \mathrm{VS} \mathrm{d}^{-1}\right)>$ group $\mathrm{B}$ $\left(11.62 \mathrm{~mL} \mathrm{~g}^{-1} \mathrm{VS} \mathrm{d}^{-1}\right)>$ group D $\left(6.58 \mathrm{~mL} \mathrm{~g}^{-1} \mathrm{VS} \mathrm{d}^{-1}\right)$. Similarly, cumulative biogas production was also found to be highest for group A (137.73 $\left.\mathrm{mL} \mathrm{g}^{-1} \mathrm{VS}\right)$, followed by groups B (101.76 $\left.\mathrm{mL} \mathrm{g}^{-1} \mathrm{VS}\right), \mathrm{C}\left(89.35 \mathrm{~mL} \mathrm{~g}^{-1} \mathrm{VS}\right)$, and $\mathrm{D}$ $\left(44.81 \mathrm{~mL} \mathrm{~g}^{-1} \mathrm{VS}\right)$. Hence, thermal pretreatment could enhance the biogas production potential resulting in enhanced ultimate biogas yield as shown in Figures 5(a) and 5(b).

\section{Modelling}

Analysis of experimental data has been performed in MSExcel and Curve Expert 1.4 using the solver feature by nonlinear regression. Figures 6(a) and 6(b) represent linear model fitting of biogas production rates for all the groups according to (1) mentioned earlier. The coefficient of determination and standard error values have been determined for all the mathematical models and tabulated in Tables 4 and 5. The coefficient $\left(R^{2}\right)$ including both the ascending and descending 


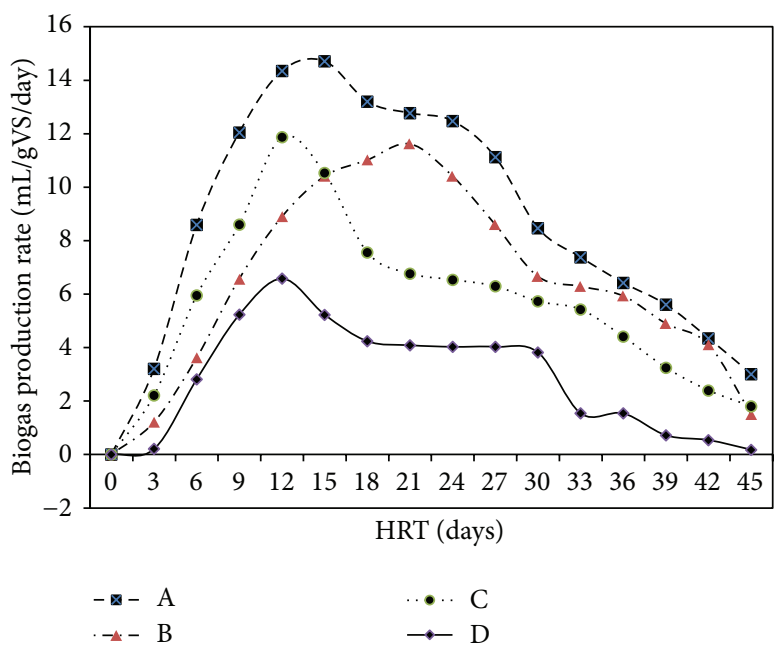

(a)

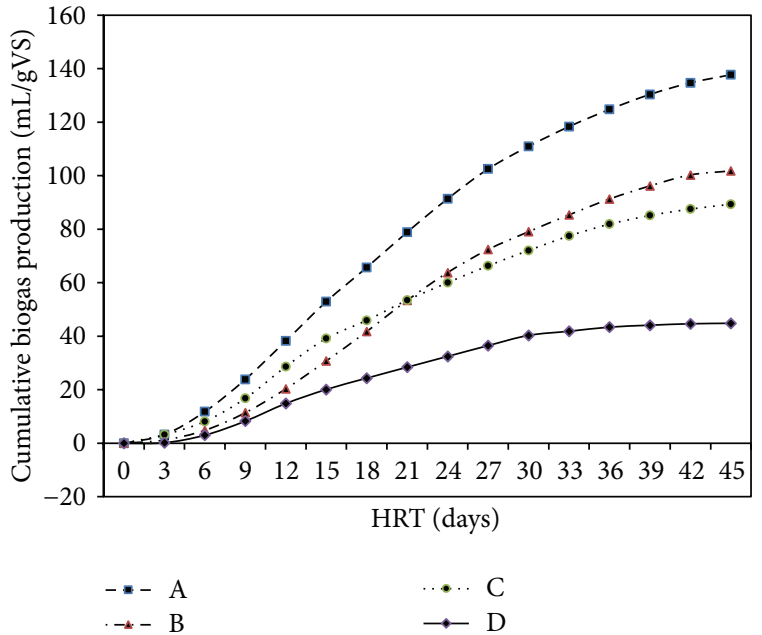

(b)

Figure 5: (a) Biogas production rate of thermally treated (A and B), untreated (C) biomass and inoculum (D) for a retention time of 45 days. (b) Cumulative biogas production of thermally treated (groups A and B), untreated (group C) biomass and inoculum (group D) for a retention time of 45 days.

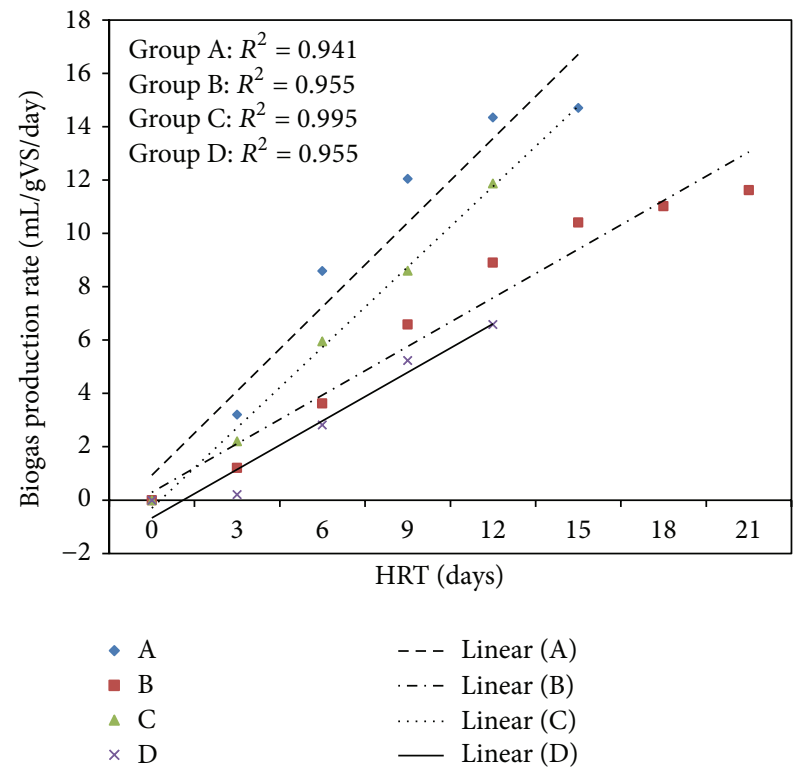

(a)

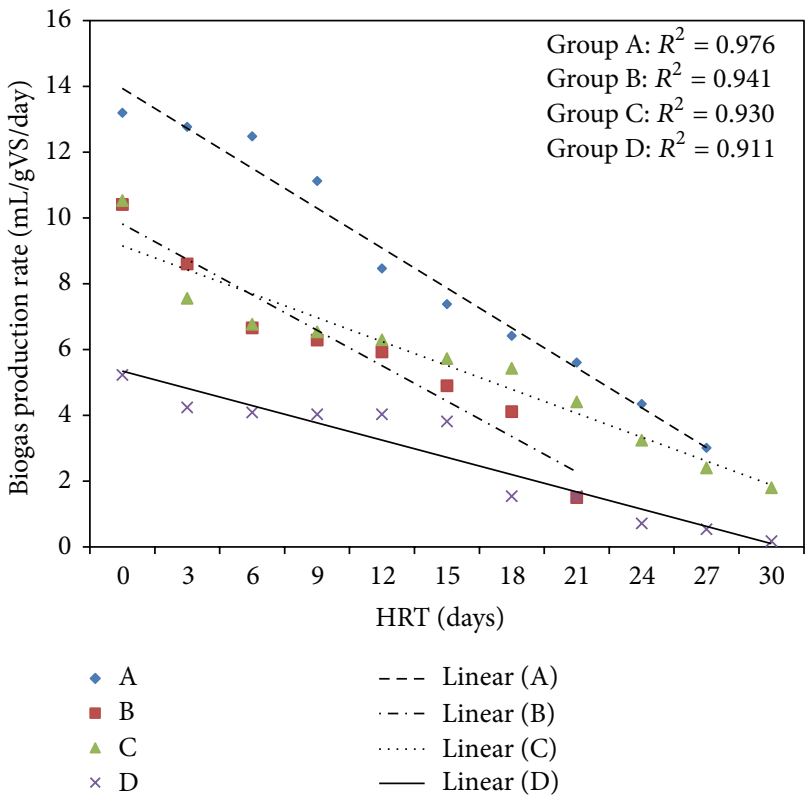

(b)

FIGURE 6: (a) Linear plot of the ascending limb of biogas production rate for thermally treated (groups A and B), untreated (group C) biomass and inoculum (group D). (b) Linear plot of the descending limb of biogas production rate for thermally treated (groups A and B), untreated (group C) biomass and inoculum (group D).

limbs for all the groups ranged from 0.911 to 0.976 . Similarly, Figures 7(a) and 7(b) show the exponential plot of biogas production rates including the ascending and descending limbs for each case. The coefficient of determination $R^{2}$ for the ascending and descending limb has been observed to be in the range of 0.441-0.989, which signifies that linear regression was better than that of exponential plot. The coefficient $R^{2}$ for ascending limb shown in Figure 7(a) ranged from 0.973 to
0.989 , which is far better than the $R^{2}$ values of the descending limb as shown in Figure 7(b). Comparing Figures 6(a), 7(a), $6(\mathrm{~b})$, and $7(\mathrm{~b})$ we can say that the $R^{2}$ values are better in case of exponential curve fitting for ascending limb and linear model fitting is better for descending limb. Hence, biogas production increases exponentially with time and reaches a peak value at a particular time period and then decreases linearly with time to a very low significant value. 


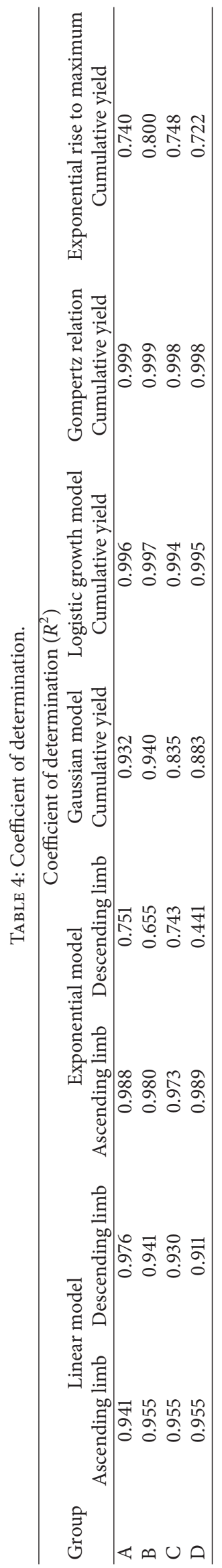




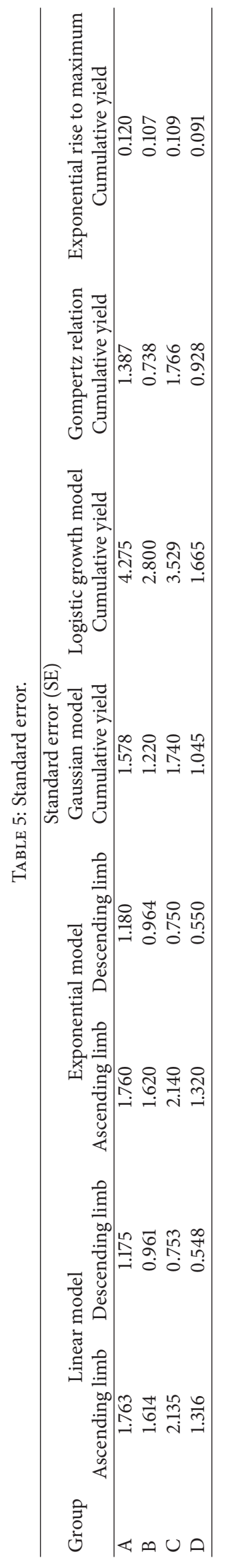




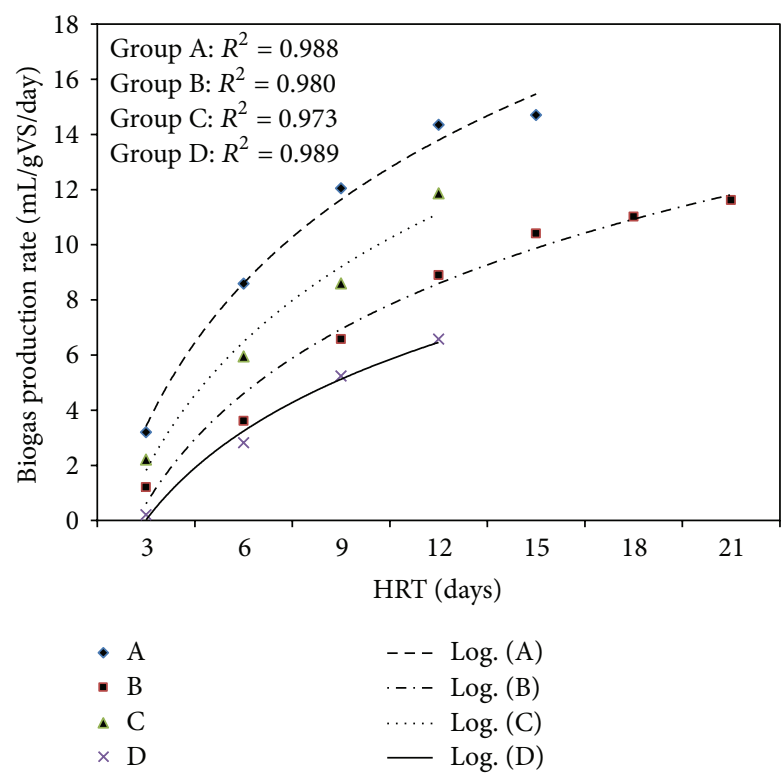

(a)

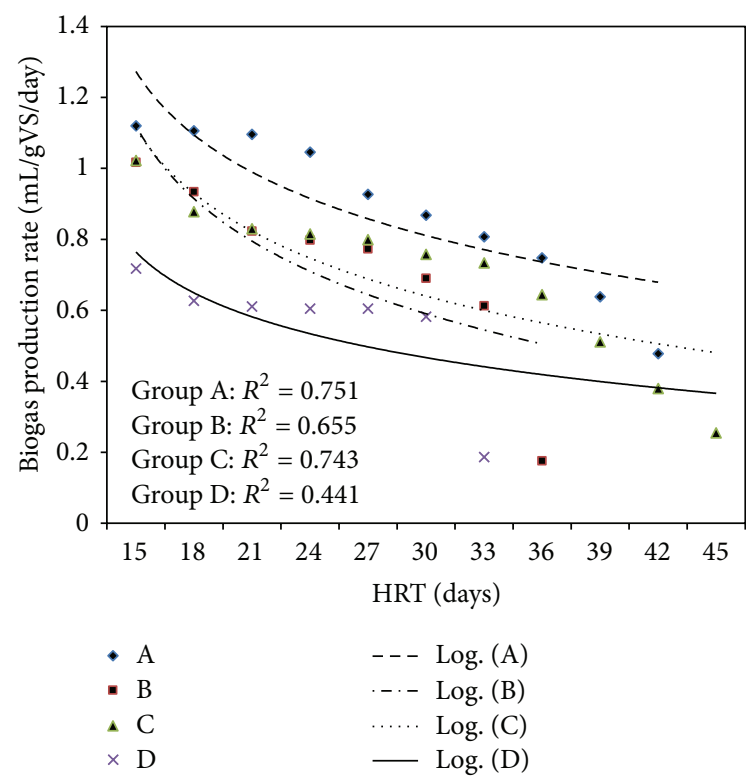

(b)

FiguRE 7: (a) Exponential plot of the ascending limb of biogas production rate for thermally treated (groups A and B), untreated (group C) biomass and inoculum (group D). (b) Exponential plot of the descending limb of biogas production rate for thermally treated (groups A and B), untreated (group C) biomass and inoculum (group D).

The experimental data has been also fitted to Gaussian model according to (3) and represented in Figures 8(a)-8(d). The coefficient $R^{2}$ was highest for group $\mathrm{B}$ and observed in the order of group $\mathrm{B}>$ group $\mathrm{A}>$ group $\mathrm{D}>$ group $\mathrm{C}$. This signifies that Gaussian plot of biogas production rate is ideal for biogas production at specified conditions associated with group B.

Cumulative biogas production represented in Figure 5(b) has been simulated using the logistic growth model, Gompertz relation, and exponential rise to maximum model. Figures 9(a)-9(d) and 10(a)-10(d) show logistic and Gompertz relation plots.

The coefficient $R^{2}$ has been observed to be in the range of 0.994-0.997 for logistic plot with maximum $R^{2}$ value for group $B$, which signifies that logistic plot for cumulative biogas production is ideal for group $B$ at specified conditions. For the Gompertz relation, the $R^{2}$ value ranged from 0.998 to 0.999 indicating better coefficient of determination compared to that of logistic model plot. In logistic growth equation, the kinetic constant " $k$ " has been found to be in the order of group D (1.758) > group B (1.598) > group A (1.527) > group $\mathrm{C}$ (1.494), but cumulative biogas production was in the order of group A $(137.73 \mathrm{~mL} / \mathrm{g} \mathrm{VS})>$ group B $(101.76 \mathrm{~mL} / \mathrm{g} \mathrm{VS})>$ group C $(89.35 \mathrm{~mL} / \mathrm{g} \mathrm{VS})>$ group D $(44.81 \mathrm{~mL} / \mathrm{g} \mathrm{VS})$.

Figure 10(e) shows that experimental cumulative yield of biogas is graphically almost close to simulated results of Gompertz relation curve fitting of cumulative yield of biogas. It signifies that cumulative yield of biogas from biomass follows nonlinear relationship with retention time.

In Figure 11 cumulative biogas production has been simulated using (6) and exponential rise to maximum plots has been presented of which the $R^{2}$ values ranged from 0.722 to 0.800 , indicating poor correlation as compared with Gompertz relation and logistic growth model plots.

\section{Approximate Analysis of Cost-Benefit Ratio}

Significant amount of energy has been required for preconditioning of biomass prior to anaerobic digestion. The approximate cost-benefit ratio has been evaluated on the basis of total input energy required for anaerobic digestion divided by the output energy equivalent of biogas yield.

6.1. Calculations for Input Energy Needed for Thermal Pretreatment. It has been assumed that at pretreatment temperatures of $85^{\circ} \mathrm{C}$ and $135^{\circ} \mathrm{C}$ only superficial moisture gets vaporized. Initially $1.0 \mathrm{~g}$ of sample biomass has been taken for analysis separately. All necessary calculations for $1.0 \mathrm{~g}$ sample have been further made for the actual amount (dry weight basis) of pretreated biomass charged into reactors (groups A and B) for anaerobic digestion:

Weight of sample biomass taken for analysis $=1.0 \mathrm{~g}$. Latent heat of vaporization of water $=540 \mathrm{cal} \mathrm{g}^{-1}$. Initial moisture content of sample biomass $=12 \%$.

Final (after pretreatment) moisture content of sample biomass $=5 \%$.

Reduction in moisture content of sample biomass = $7 \%$.

Energy required to remove moisture from $1.0 \mathrm{~g} \mathrm{sam}$ ple biomass $=(540 \times 0.07)=37.8 \mathrm{cal} \mathrm{g}^{-1}$.

Number of test reactors considered for study of pretreated sample biomass $=2$. 


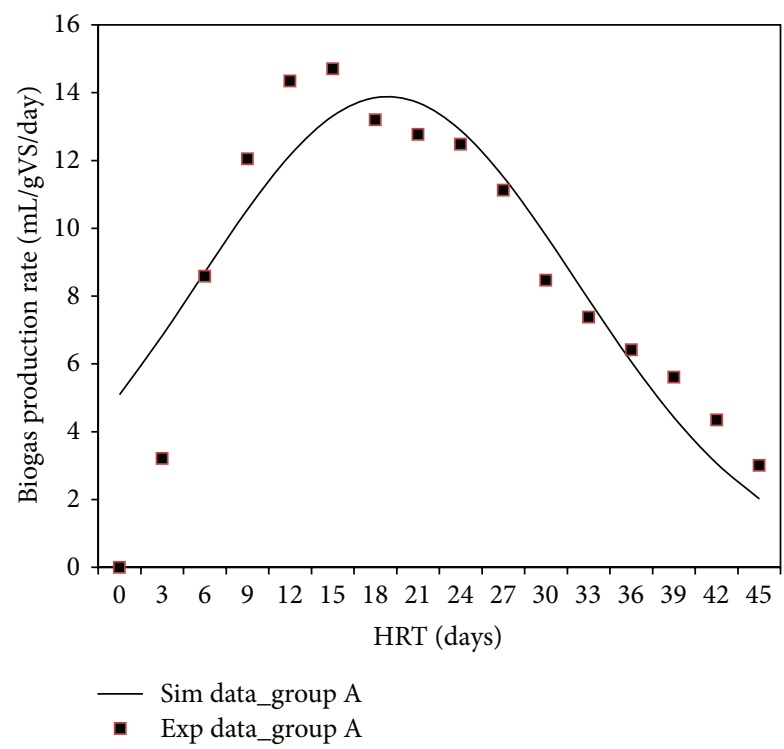

(a)

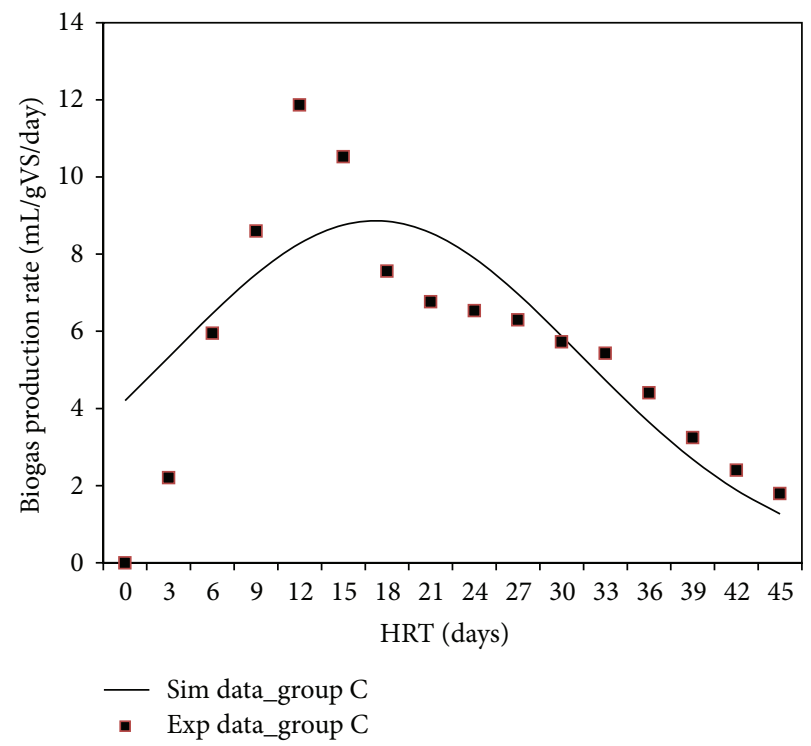

(c)

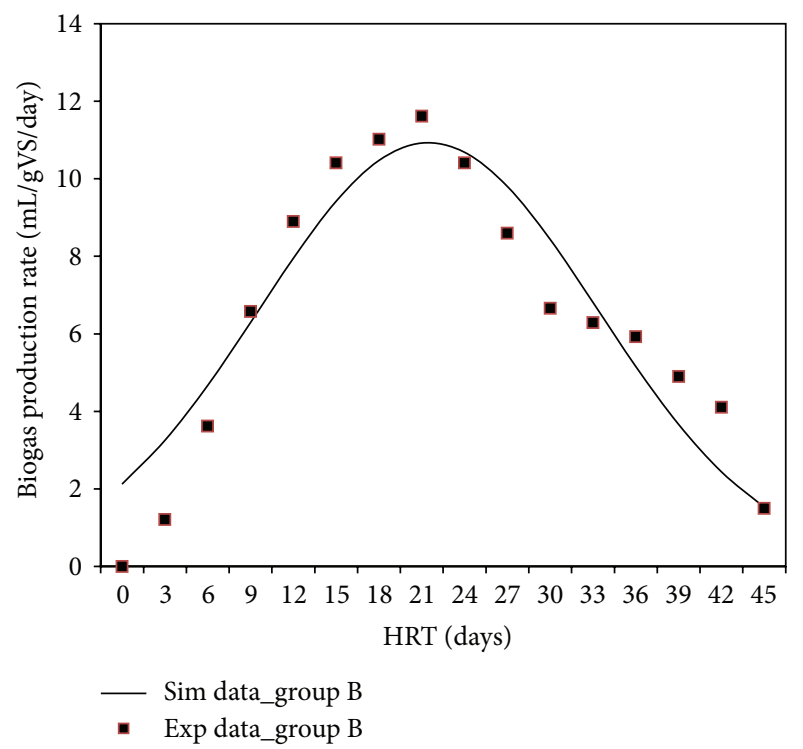

(b)

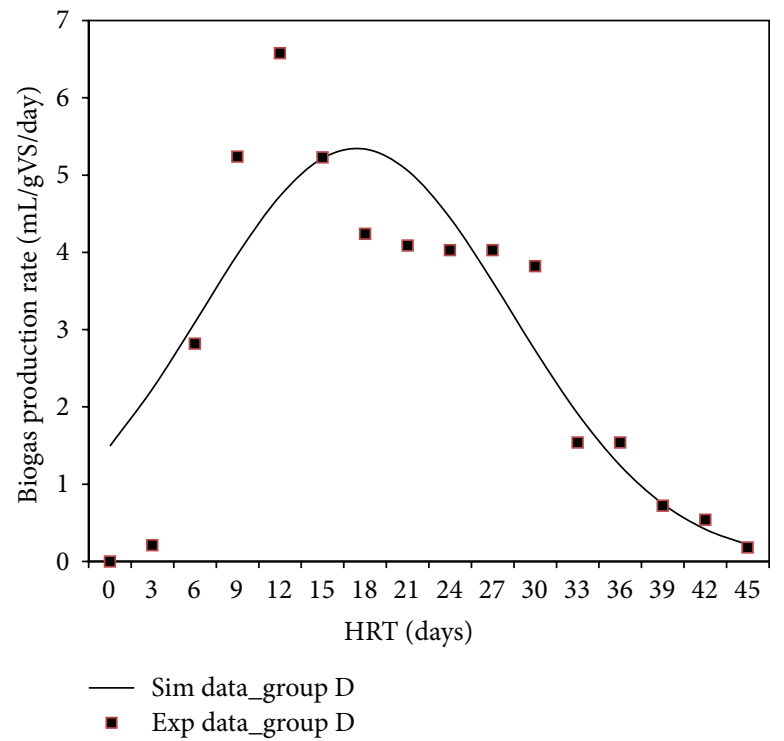

(d)

FIGURE 8: (a) Gaussian plot of cumulative biogas production for thermally treated biomass at $135^{\circ} \mathrm{C}$ (group A). (b) Gaussian plot of cumulative biogas production for treated biomass at $85^{\circ} \mathrm{C}$ (group B). (c) Gaussian plot of cumulative biogas production for untreated biomass (group C). (d) Gaussian plot of cumulative biogas production for the inoculum (group D).

Total solid (TS) of biomass charged into each reactor $=75.0 \mathrm{~g}$.

Total solid (TS) of biomass content of 2 reactors (groups $\mathrm{A}$ and $\mathrm{B})=(75 \times 2)=150 \mathrm{~g}$.

Energy required to remove moisture from total solids of biomass of 2 reactors $=(150 \times 37.8)=5670 \mathrm{cal}=$ $5.67 \mathrm{kcal}\left(E_{\text {in } 1}\right)$.

6.2. Calculations for Input Energy Needed for Anaerobic Digestion. Amount of heat required to raise the slurry to reactor operating temperature $\left(35^{\circ} \mathrm{C}\right)$ has been calculated from

$$
Q_{i}=W_{g} C_{p}\left(T-T_{s}\right),
$$

where $T$ is digester temperature $\left({ }^{\circ} \mathrm{C}\right), T_{s}$ is influent slurry temperature $\left({ }^{\circ} \mathrm{C}\right), W_{g}$ is total weight of slurry added to reactor, $C_{p}$ is specific heat capacity of added slurry, and $C_{p}$ is given by the equation

$$
C_{p}=4.19-0.00275[\mathrm{TS}] .
$$




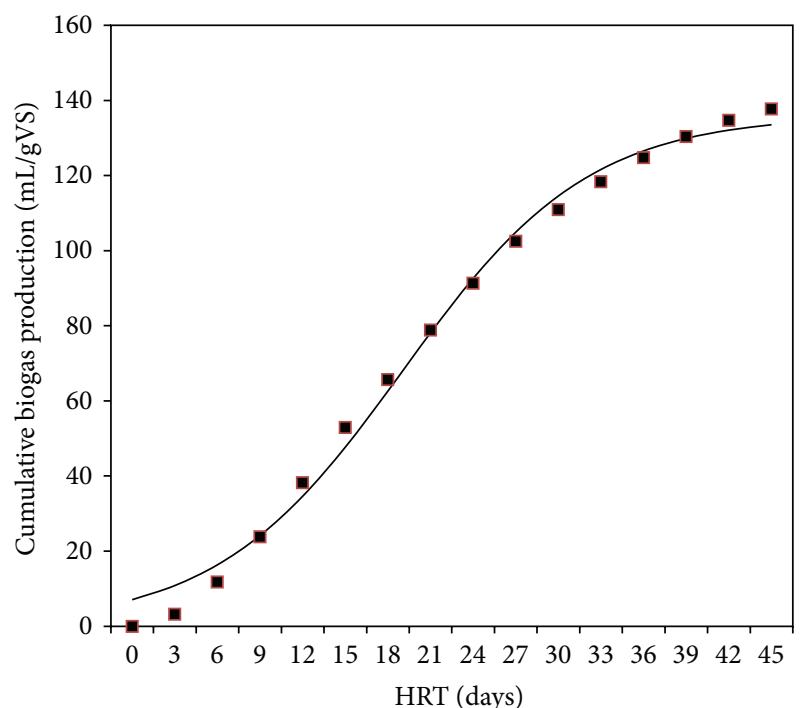

- Sim data_group A

- Exp data_group A

(a)

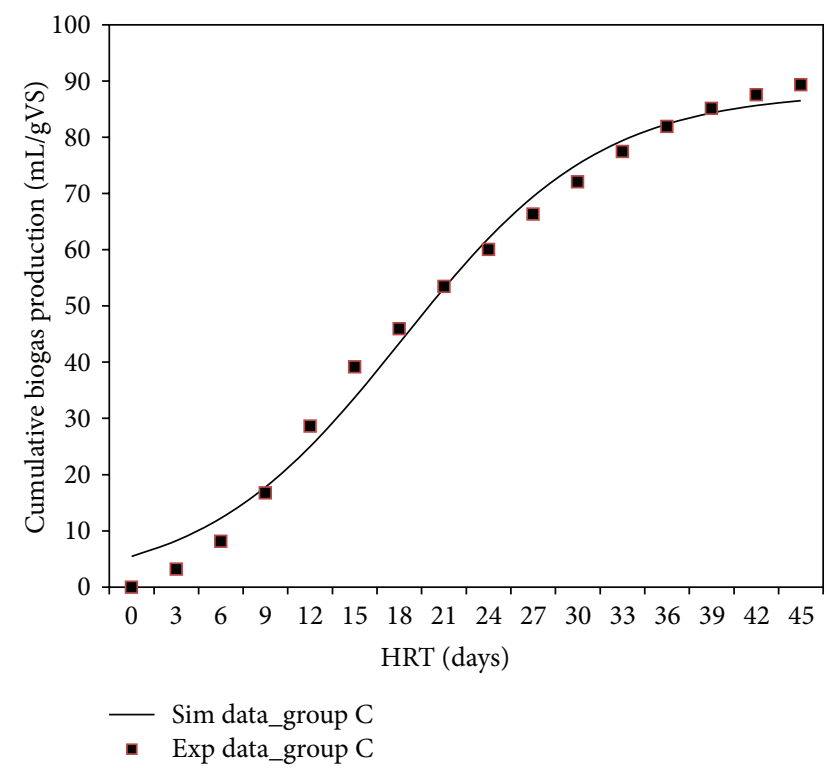

(c)

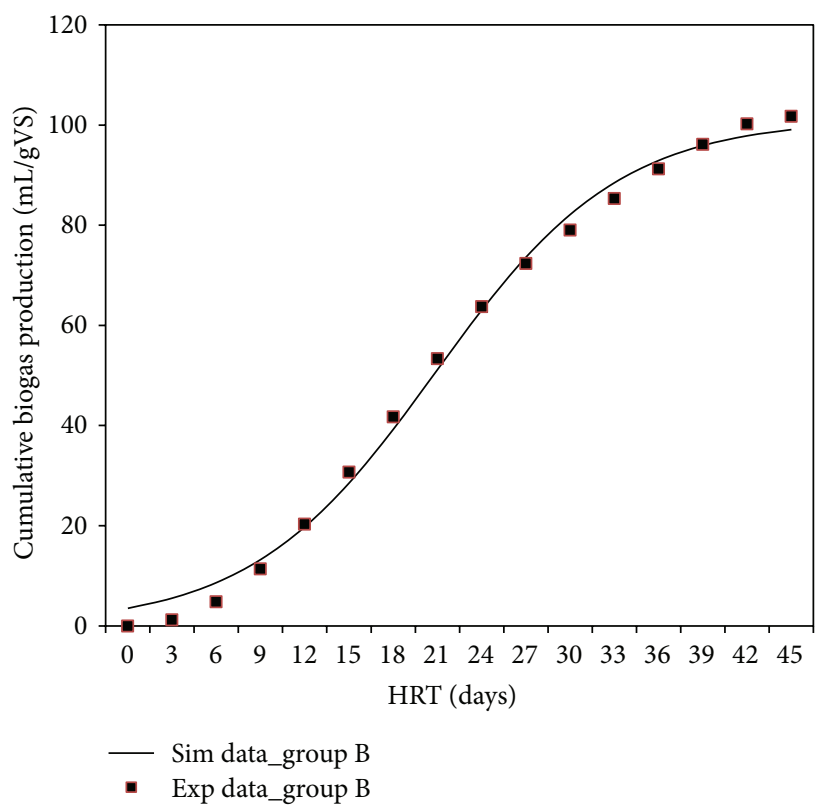

(b)

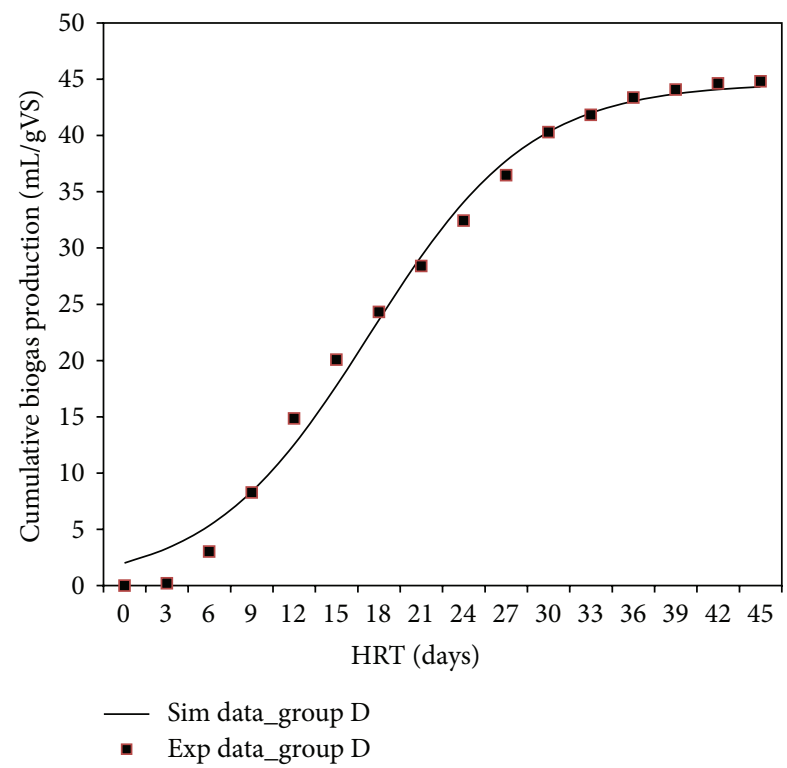

(d)

FIGURE 9: (a) Logistic growth model plot of cumulative biogas production for treated biomass at $135^{\circ} \mathrm{C}$ (group A). (b) Logistic growth model plot of cumulative biogas production for treated biomass at $85^{\circ} \mathrm{C}$ (group B). (c) Logistic growth model plot of cumulative biogas production for untreated biomass (group C). (d) Logistic growth model plot of cumulative biogas production for inoculum (group D).

TS (total solid) is expressed in $\mathrm{Kg} \mathrm{m}^{-3}$. Hence, $C_{p}=$ $3.915 \mathrm{KJ} \mathrm{Kg}^{-10} \mathrm{C}$. Therefore, $Q_{i}=16.14 \mathrm{KJ}=3.857 \mathrm{kcal}$. Total $Q_{i}$ for 4 reactors $=15.428 \mathrm{kcal}\left(E_{\text {in } 2}\right)$.

\subsection{Calculations for Input Energy Needed for Mechanical} Agitation or Mixing. Consider

Power consumption of motor for mixing = 26.3 watt $\mathrm{m}^{-3}$.

Reactor volume $=1000 \mathrm{~mL}=10^{-3} \mathrm{~m}^{3}$.
Hence, energy equivalent of power consumption for mixing $=26.3 \times 10^{-3} \mathrm{Js}^{-1}$.

Number of reactors $=4$.

The motor has been operated for $24 \mathrm{hrs}$ for a retention of 45 days.

Total energy needed for mixing $=26.3 \times 10^{-3} \times 3600$ $\times 24 \times 45 \times 4=409017.6 \mathrm{~J}=97.752 \mathrm{kcal}\left(E_{\text {in } 3}\right)$.

Total input energy needed $=\left(E_{\text {in } 1}+E_{\text {in } 2}+E_{\text {in 3 }}\right)=$ $118.85 \mathrm{kcal}\left(T_{E_{\text {in }}}\right)$. 


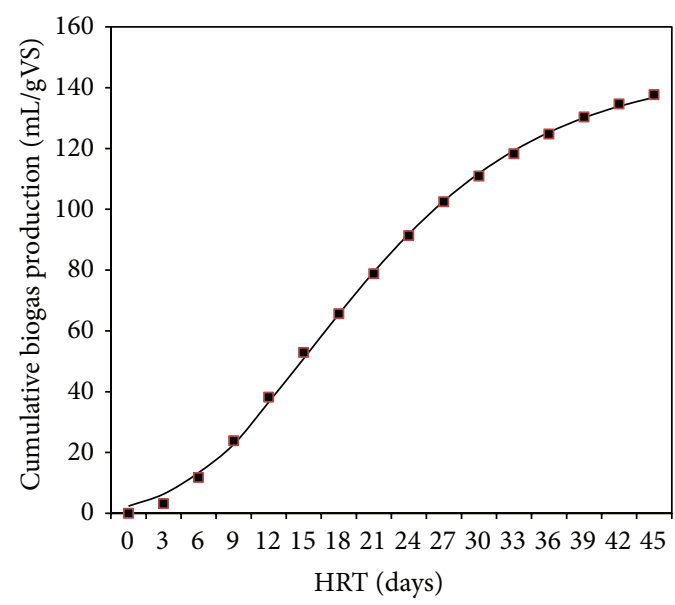

- Sim data_group A

- Exp data_group A

(a)

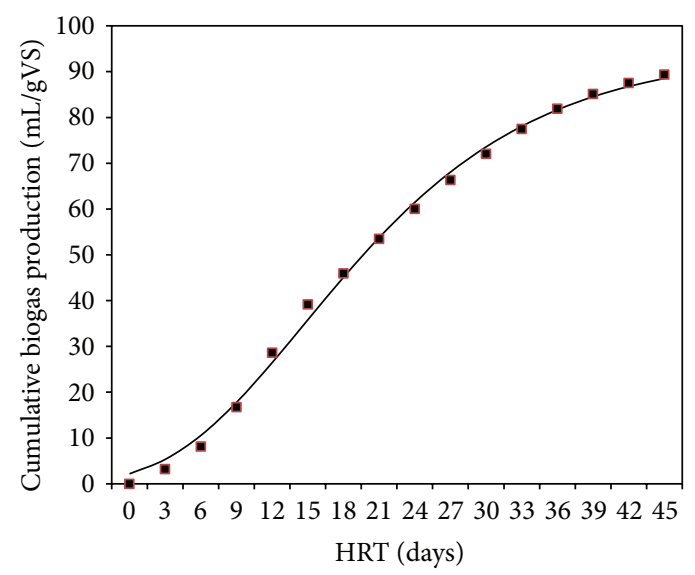

- Sim data_group C

- Exp data_group C

(c)

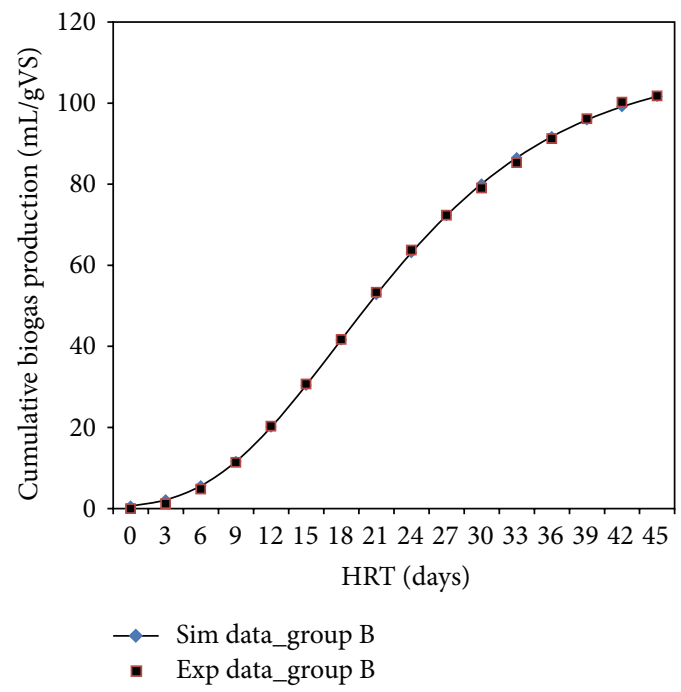

(b)

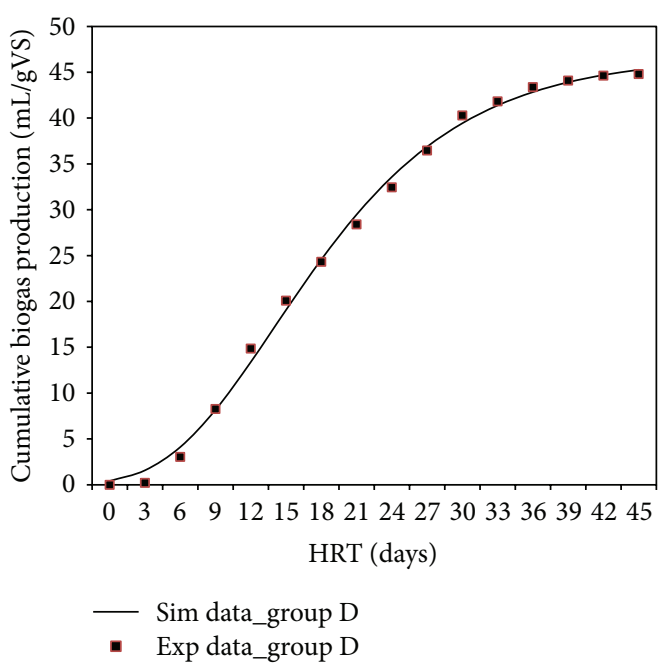

(d)

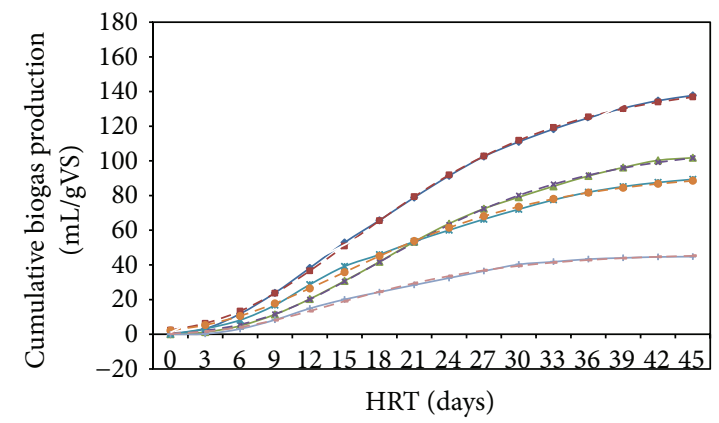

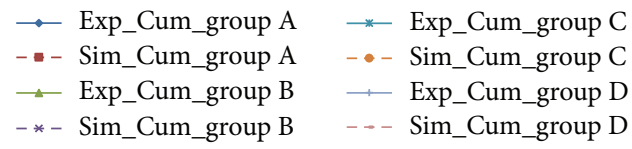

(e)

FIGURE 10: (a) Gompertz relation plot of cumulative biogas production for treated biomass at $135^{\circ} \mathrm{C}$ (group A). (b) Gompertz relation plot of cumulative biogas production for treated biomass at $85^{\circ} \mathrm{C}$ (group B). (c) Gompertz relation plot of cumulative biogas production for untreated biomass (group C). (d) Gompertz relation plot of cumulative biogas production for inoculum (group D). (e) Comparative plot for experimental and Gompertz relation simulated cumulative biogas yield. 


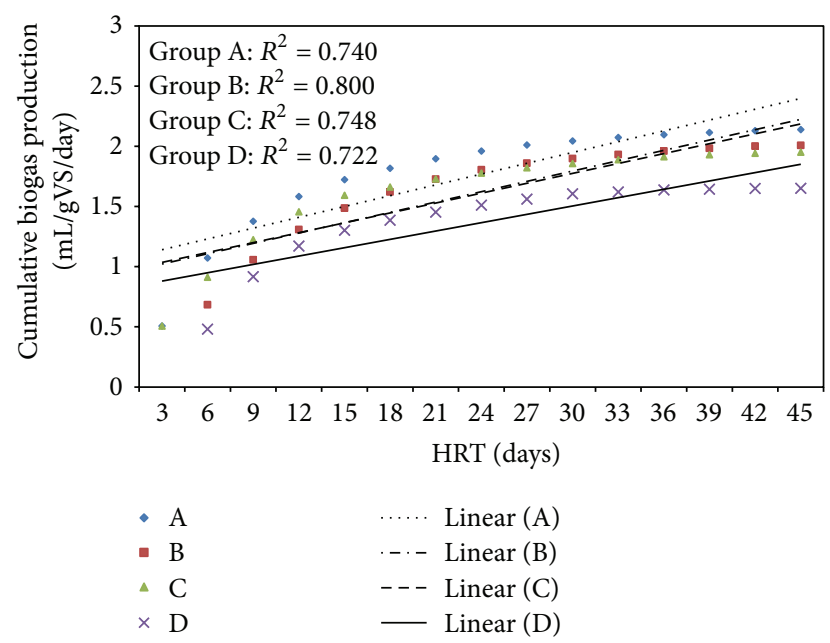

FIGURE 11: Exponential rise to maximum plot for cumulative biogas production of all the groups (A-D).

6.4. Calculations for Output Energy from Biogas Yield. Consider

Energy equivalent of biogas $=22 \mathrm{MJ} \mathrm{m}^{-3}=22 \times$ $10^{6} \mathrm{Jm}^{-3}=22 \times 10^{6} \times 0.239=5.258 \times 10^{6} \mathrm{cal} \mathrm{m}^{-3}$.

Total energy output from biogas yield of all reactors = $148.11 \mathrm{kcal}\left(T_{E_{\text {out }}}\right)$.

Cost-benefit ratio $=T_{E_{\text {in }}} / T_{E_{\text {out }}}=0.8$. Similarly, Benefit-cost ratio $=T_{E_{\text {out }}} / T_{E_{\text {in }}}=1.25$.

\section{Conclusions}

Thermal pretreatment improved the kinetics of biogas production; high temperature treatment was more effective in preconditioning of the biomass prior to anaerobic digestion and henceforth resulted in higher yield of biogas. Both biogas production potential and reactor efficiency were enhanced by thermal pretreatment which was revealed by the kinetic modeling of biogas production rates and cumulative biogas production. The approximate cost-benefit ratio of 0.8 has been evaluated on the basis of the ratio of total input energy required for anaerobic digestion to the equivalent output energy of biogas produced. Biogas production rate simulated by exponential model showed better correlation than linear plot for the ascending limb whereas the descending limb followed better correlation with linear model than exponential model. Hence, we can conclude that biogas production increases exponentially with time up to a peak value and thereafter decreases linearly with time to a very significant low value marking the end of potential for the substrates to produce biogas. Gompertz relation and logistic model plot resulted in higher correlation than exponential rise to maximum plot.

\section{Highlights}

(i) Thermal pretreatment improved the kinetics of biogas production.

(ii) Biogas production rate increased exponentially and reached a peak value and thereafter decreased linearly to a very low significant value.

(iii) Gompertz relation and logistic growth model resulted in better correlation than exponential rise to maximum for cumulative biogas production.

(iv) Cost-benefit ratio of anaerobic digestion process has been determined as 0.8 .

$\begin{array}{ll}\text { Abbreviations } \\ \text { AD: } & \text { Anaerobic digestion } \\ \text { OFMSW: } & \text { Organic fraction municipal solid waste } \\ \text { CM: } & \text { Cattle manure } \\ \text { S/I: } & \text { Substrate to inoculum ratio } \\ \text { MC: } & \text { Moisture content } \\ \text { TS: } & \text { Total solid } \\ \text { VS: } & \text { Volatile solid } \\ \text { FC: } & \text { Fixed carbon } \\ \text { BD: } & \text { Bulk density } \\ \text { ND: } & \text { Not determined } \\ \text { C/N: } & \text { Carbon to nitrogen ratio } \\ \text { COD: } & \text { Chemical oxygen demand } \\ \text { STP: } & \text { Standard temperature and pressure } \\ \text { HRT: } & \text { Hydraulic retention time. }\end{array}$

\section{Conflict of Interests}

The authors declare that there is no conflict of interests regarding the publication of this paper.

\section{Acknowledgments}

This research work has been financially supported by DST INSPIRE Fellowship for Doctoral Studies (DST/INSPIRE Fellowship/2014 Govt. of India, Ministry of Science and Technology) and research grant of the Department of Chemical Engineering, Jadavpur University. The same work has been efficiently assisted by Mr. Ashok Seal whose outreaching contribution to laboratory equipment handling made the work a success. Nevertheless, the work has been sequentially assisted from time to time for simulation and presentation by Dr. Saswata Bose (Faculty, Department of Chemical Engineering, Jadavpur University). Henceforth deep sense of gratitude is expressed for everybody who contributed to the research work for making it a grand success.

\section{References}

[1] ISAT and GTZ, Eds., Biogas Basics. (Biogas Digest, 1), Information and Advisory Services on Appropriate Technology (ISAT), German Agency for Technical Cooperation GmbH (GTZ), 1999. 
[2] T. Pipoli, "Feasibility of biomass-based fuel cells for manned space exploration," in Proceedings of the 7th European Space Power Conference, ESA Proceedings, SP-589, Stresa, Italy, May 2005, http://www.esa.int/gsp/ACT/doc/POW/ACT-RPRNRG-2005-ESPC-Feasibility\%20of\%20Biomass\%20based\% 20Fuel\%20Cells.pdf

[3] L. S. Yadava and P. R. Hesse, The Development and Use of Biogas Technology in Rural Areas of Asia (A Status Report 1981). Improving Soil Fertility through Organic Recycling, Food and Agriculture Organization (FAO), United Nations Development Program (UNEP), 1981.

[4] M. D. Ghatak and P. Mahanta, "Comparison of kinetic models for biogas production rate from saw dust," International Journal of Research in Engineering and Technology, vol. 3, no. 7, pp. 248254, 2014

[5] I. Angelidaki, L. Ellegaard, and B. K. Ahring, "A mathematical model for dynamic simulation of anaerobic digestion of complex substrates: focusing on ammonia inhibition," Biotechnology and Bioengineering, vol. 42, no. 2, pp. 159-166, 1993.

[6] R. Boopathy, V. F. Larsen, and E. Senior, "Performance of anaerobic baffled reactor (ABR) in treating distillery waste water from a Scotch Whisky factory," Biomass, vol. 16, no. 2, pp. 133143, 1988.

[7] D. Garcia-Calderon, P. Buffiere, R. Moletta, and S. Elmaleh, "Anaerobic digestion of wine distillery wastewater in down-flow fluidized bed," Water Research, vol. 32, no. 12, pp. 3593-3600, 1998.

[8] S. K. Goyal, R. Seth, and B. K. Handa, "Diphasic fixed-film biomethanation of distillery spentwash," Bioresource Technology, vol. 56, no. 2-3, pp. 239-244, 1996.

[9] D. T. Hill and C. L. Barth, "A dynamic model for simulation of animal waste digestion," Journal of the Water Pollution Control Federation, vol. 49, no. 10, pp. 2129-2143, 1977.

[10] S. Jeyaseelan, "A simple mathematical model for anaerobic digestion process," Water Science and Technology, vol. 35, no. 8, pp. 185-191, 1997.

[11] S. Kumar, A. N. Mondal, S. A. Gaikwad, S. Devotta, and R. N. Singh, "Qualitative assessment of methane emission inventory from municipal solid waste disposal sites: a case study," Atmospheric Environment, vol. 38, no. 29, pp. 4921-4929, 2004.

[12] H. M. Lo, T. A. Kurniawan, M. E. T. Sillanpää et al., "Modeling biogas production from organic fraction of MSW co-digested with MSWI ashes in anaerobic bioreactors," Bioresource Technology, vol. 101, no. 16, pp. 6329-6335, 2010.

[13] E. V. Münch, J. Keller, P. Lant, and R. Newell, "Mathematical modelling of prefermenters-I. Model development and verification," Water Research, vol. 33, no. 12, pp. 2757-2768, 1999.

[14] H. Carrère, C. Dumas, A. Battimelli et al., "Pretreatment methods to improve sludge anaerobic degradability: a review," Journal of Hazardous Materials, vol. 183, no. 1-3, pp. 1-15, 2010.

[15] M. Carlsson, A. Lagerkvist, and F. Morgan-Sagastume, "The effects of substrate pre-treatment on anaerobic digestion systems: a review," Waste Management, vol. 32, no. 9, pp. 1634-1650, 2012.

[16] A. Cesaro and V. Belgiorno, "Pretreatment methods to improve anaerobic biodegradability of organic municipal solid waste fractions," Chemical Engineering Journal, vol. 240, pp. 24-37, 2014.

[17] J. B. Bien, G. Malina, J. D. Bien, and L. Wolny, "Enhancing anaerobic fermentation of sewage sludge for increasing biogas generation," Journal of Environmental Science and Health A, vol. 39, no. 4, pp. 939-949, 2004.
[18] I. Ferrer, S. Ponsá, F. Vázquez, and X. Font, "Increasing biogas production by thermal $\left(70{ }^{\circ} \mathrm{C}\right)$ sludge pre-treatment prior to thermophilic anaerobic digestion," Biochemical Engineering Journal, vol. 42, no. 2, pp. 186-192, 2008.

[19] J. Marin, K. J. Kennedy, and C. Eskicioglu, "Effect of microwave irradiation on anaerobic degradability of model kitchen waste," Waste Management, vol. 30, no. 10, pp. 1772-1779, 2010.

[20] A. Prorot, L. Julien, D. Christophe, and L. Patrick, "Sludge disintegration during heat treatment at low temperature: a better understanding of involved mechanisms with a multiparametric approach," Biochemical Engineering Journal, vol. 54, no. 3, pp. 178-184, 2011.

[21] A. Mottet, J. P. Steyer, S. Déléris, F. Vedrenne, J. Chauzy, and H. Carrère, "Kinetics of thermophilic batch anaerobic digestion of thermal hydrolysed waste activated sludge," Biochemical Engineering Journal, vol. 46, no. 2, pp. 169-175, 2009.

[22] A. Hendriks and G. Zeeman, "Pretreatments to enhance the digestibility of lignocellulosic biomass," Bioresource Technology, vol. 100, no. 1, pp. 10-18, 2009.

[23] J. Ariunbaatar, A. Panico, G. Esposito, F. Pirozzi, and P. N. L. Lens, "Pretreatment methods to enhance anaerobic digestion of organic solid waste," Applied Energy, vol. 123, pp. 143-156, 2014.

[24] B. Budiyono, I. N. Widiasa, S. Sunarso, and J. Seno, "The kinetic of biogas production rate from cattle manure in batch mode," International Journal of Chemical and Biological Engineering, vol. 3, no. 1, pp. 39-45, 2010.

[25] A. Nopharatana, P. C. Pullammanappallil, and W. P. Clarke, "Kinetics and dynamic modelling of batch anaerobic digestion of municipal solid waste in a stirred reactor," Waste Management, vol. 27, no. 5, pp. 595-603, 2007.

[26] Y. Jiang, S. Heaven, and C. J. Banks, "Strategies for stable anaerobic digestion of vegetable waste," Renewable Energy, vol. 44, pp. 206-214, 2012.

[27] E. T. Iyagba, I. A. Mangibo, and Y. S. Mohammad, "The study of cow dung as co-substrate with rice husk in biogas production," Scientific Research and Essays, vol. 4, no. 9, pp. 861-866, 2009.

[28] A. Das and C. Mondal, "Catalytic effect of tungsten on anaerobic digestion process for biogas production from fruit and vegetable wastes," International Journal of Scientific Engineering and Technology, vol. 2, no. 4, pp. 216-221, 2013. 

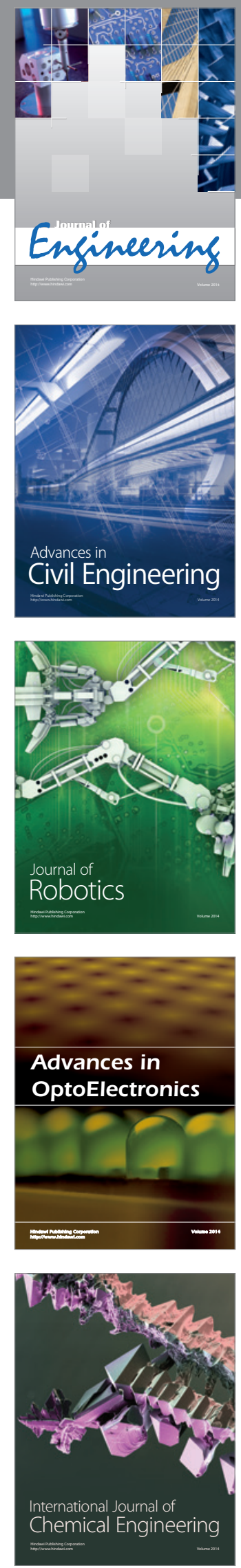

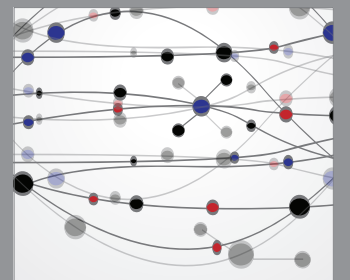

The Scientific World Journal
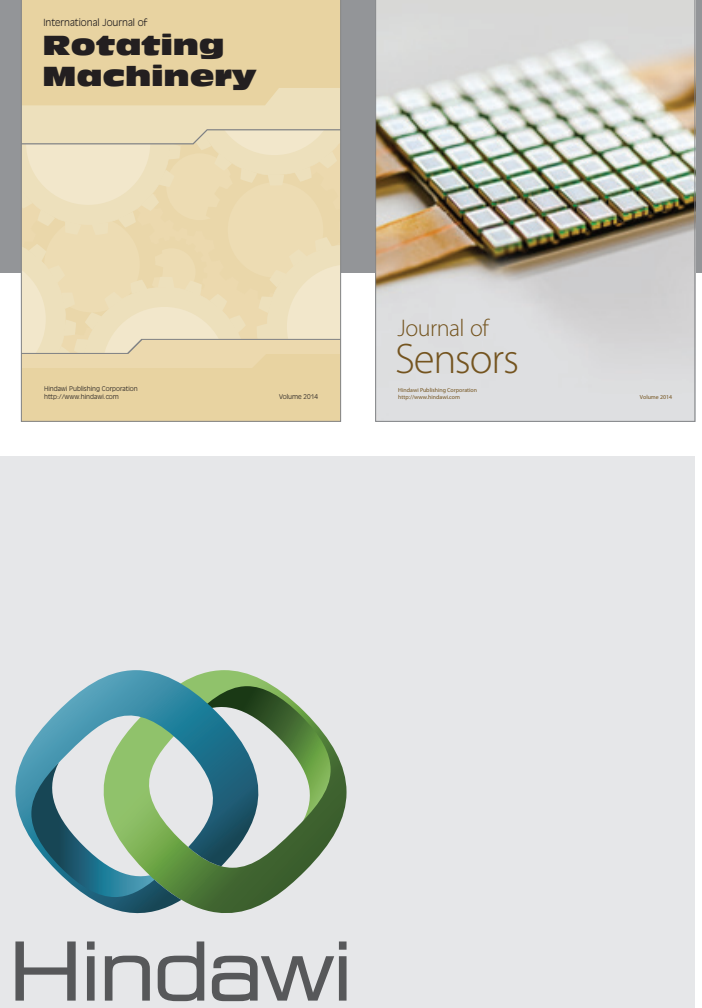

Submit your manuscripts at http://www.hindawi.com
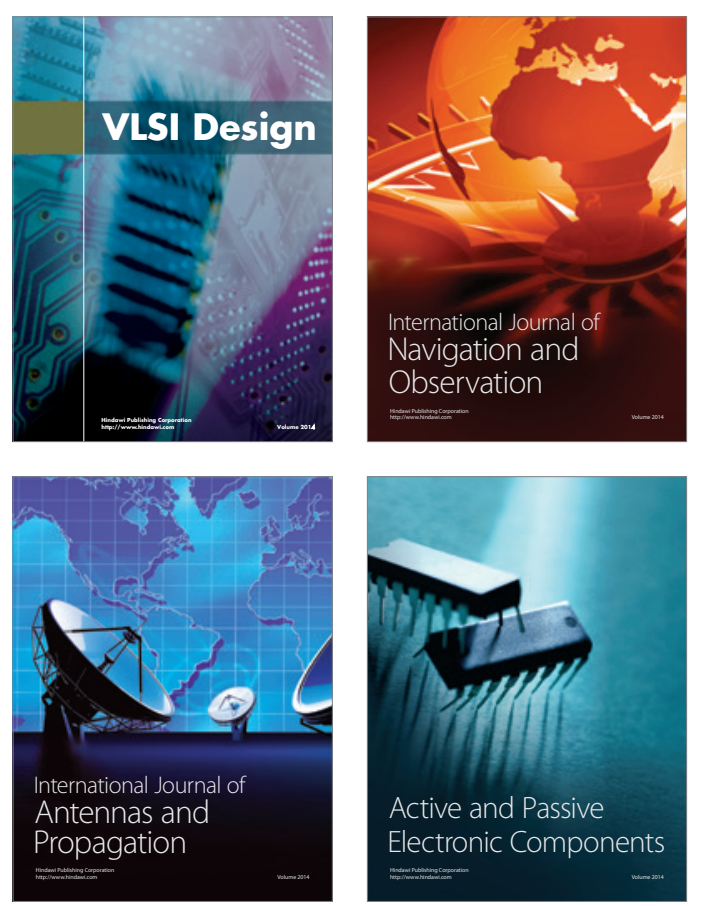
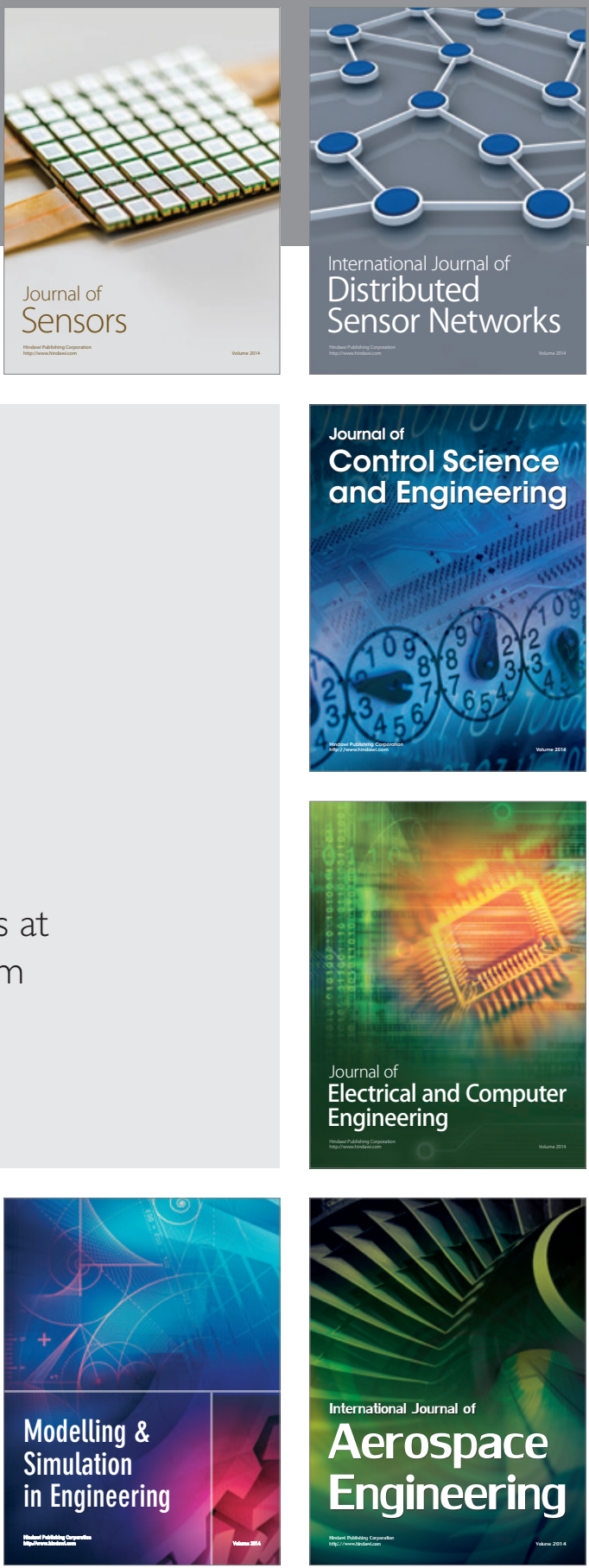

Journal of

Control Science

and Engineering
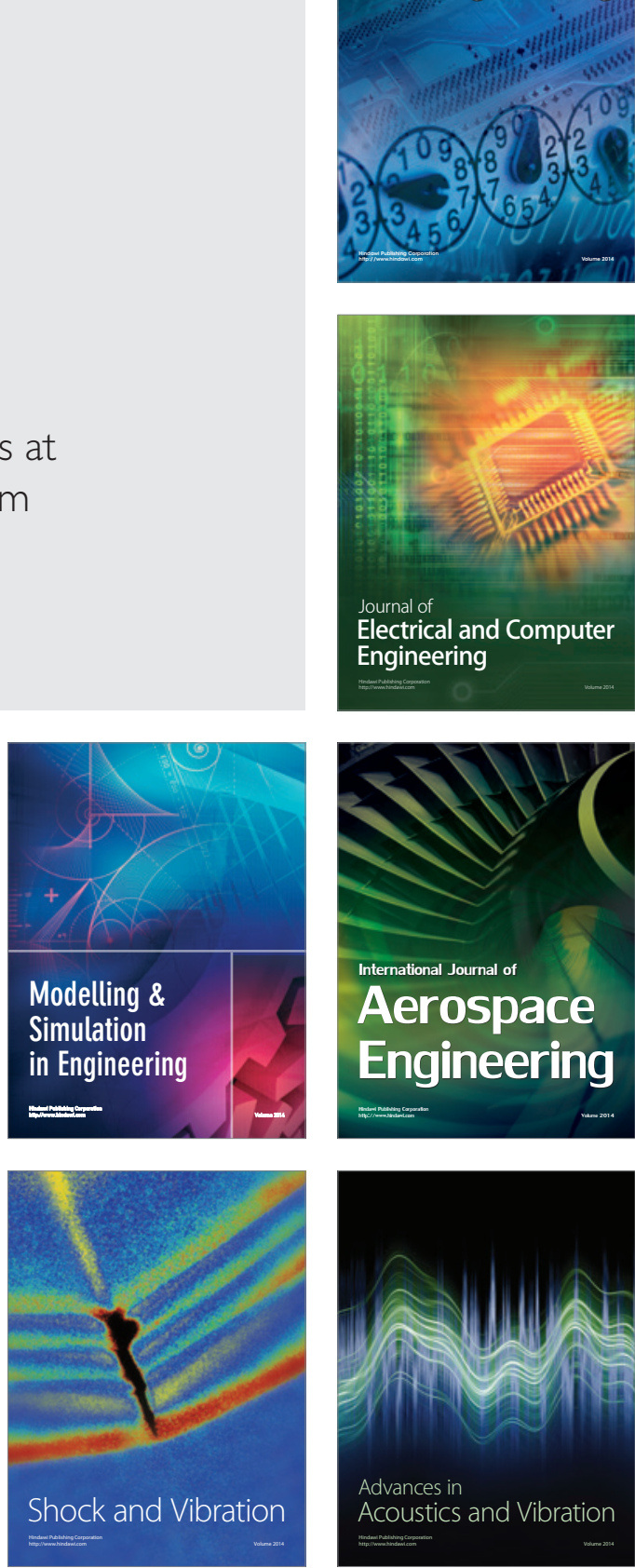